\title{
Three Additions to the Flora of Saskatchewan
}

\author{
by B. de Vries, University of Alberta, Calgary
}

Among the plants collected in the course of a botanical field trip in the Missouri Coteau during the summer of 1962 three specimens, Cicer arietinum, Lathyrus sativus and Malva sylvestris mauritiana, were of special interest, as they were apparently new to the region. A close check of the literature indicates that all three are new to Saskatchewan and that one of them is a first collection for Canada.

Vouaher specimens of these three species are deposited in the Herbarium of the Canada Department of Agriculture, Ottawa (DAO) and in the author's private herbarium. Pertinent information on the three collections, which were all taken on the Hafichuck ranch, SW. 6-16-28 W2, in the Missouri Coteau about 10 miles SSE of Caron, is as follows::

Cicer arietinum L. de Vries \#1429. Collected in what was assumed to be an abandoned garden plot. This species has been reported in Manitoba from Erickson, $68 \mathrm{~km}$. north of Brandon, by Percival in 1922, and from Winnipeg, Selkirk and St. Eustache by Groh and Frankton in 1949 ( $H$. J. Scoggan, 1957. Flora of Manitoba, Nat. Mus. Bull. \#140). It is native to southwest Asia and it appears only as a rather infrequent escape in Canada.

Lathyrus sativus L. de Vries \#1430. Found in association with Cicer arietinum. Gleason (New Britton and Brown Illustrated Flora. 1952. Vol. 2, p. 446) says that it has been "long in cultivation in Europe" but that it occurs only rarely in North America as an adventive about eastern seaports.

Malva sylvestris L. var. mauriitana (L.) Boiss. de Vries \#1463. Collected in a waste area subjected to much trampling by cattle and disturbance by domestic fowl. This is an introduced species from Eurasia which has been found frequently escaped from cultivation in waste places and along roadsides. Stevens (Handbook of North Dakota Plants, 1950. p. 206) reports it from Cass, La Moure, and Stutsman counties in North Dakota as a garden escape. Although not the first collection, this specimen seems to be the first actually reported for Saskatchewan (B. Boivin, personal communication, 1963).

Unusual plants, such as the three listed here, are occasionally encountered and it is always interesting to speculate on how they came into and became established in the area. Since Cicer arietinum and Lathyrus sativus were collected in what appeared to have been a garden plot they may have been accidentally introduced with domestic garden seeds. An alternative suggestion is that the parental seeds might migiht been introduced with imported hay as this area had been used as a cattle feeding ground in the past. The soil in which these plants grew was moist, well aerated, and brown in colour. The plants appeared to be in thriving condition, and to judge from the size of the populations, these two annual species are both well established and are producing seeds successfully each year.

Malva sylvestris var. mauritiana on the other hand, was poorly established in tightly packed dry soil. The vegetation of the area consisted mostly of Polygonum achoreum and Malva parviflora. Only two plants were found and they might have been introduced accidentally with seed imports.

I wish to thank the Saskatchewan Natural History Society for a grant which aided in carrying out this work. I wish also to thank Dr. B. Boivin, Canada Department of Agriculture, Ottawa, who kindly checked my identifications, and Dr. C. D. Bird, Biology Department, University of Alberta, Calgary, for reviewing this manuscript and for providing critical comments. 